
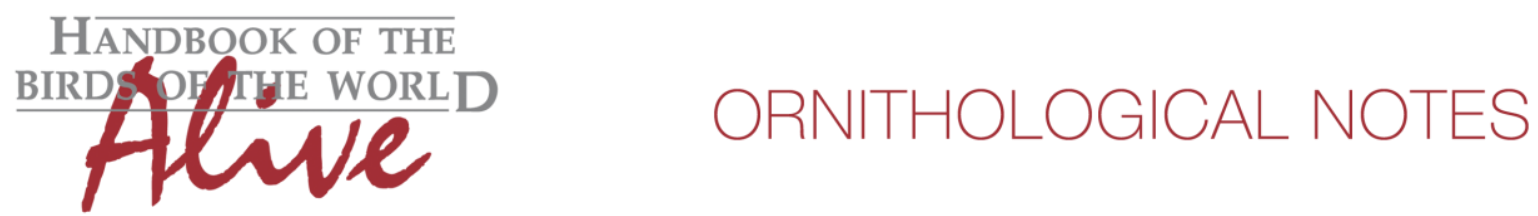

\title{
Notes on the vocalizations of Ornate Flycatcher (Myiotriccus ornatus)
}

Peter Boesman

In the following we briefly analyze and compare voice of the different races of Ornate Flycatcher (Myiotriccus ornatus). We also try to quantify the extent of any vocal differences using the criteria proposed by Tobias et al. (2010), as a support for taxonomic review. We have made use of sound recordings available on-line from Xeno Canto (XC) and Macaulay Library (ML).

Song is a single emphatic note followed by a fast series of 3-8 similar stuttered notes (Fig. 1).

$\begin{array}{ll}\text { Western birds: ornatus (with stellatus } \\ \text { Longest note } & 0.075-0.11 \mathrm{~s} \\ \text { max. freq. } & 6200-6900 \mathrm{~Hz} \\ \text { av. pace* } & 0.14-0.25 \mathrm{~s} \\ \text { max. pace* } & 0.11-0.23 \mathrm{~s}\end{array}$

Eastern birds: phoenicurus (with aureiventris) $(n=7)$

Longest note $\quad 0.08-0.10 \mathrm{~s}$

max. freq. $\quad 6080-6560 \mathrm{~Hz}$

av. pace* $\quad 0.09-0.12 \mathrm{~s}$

max. pace* $\quad 0.088-0.12 \mathrm{~s}$

(*: pace here expressed as period, the duration between two subsequent notes)

Both groups have a very similar song, but there seems to be a difference in pace of the repeated notes: phoenicurus (with aureiventris) utters the series of notes consistently at a faster pace (score 2).

Also, in the available recordings, for phoenicurus (with aureiventris) the song structure is always a single (or double) note, followed by a clear pause, followed by the rapid series of notes. In ornatus (with stellatus), this structure is not always that clear, with often the pause after the first note not much longer than the subsequent pauses.

The vocal differences are thus minor, when applying Tobias criteria they would lead to a total vocal score of 2 .

This note was finalized on 23 rd July 2015 , using sound recordings available on-line at that moment. We would like to thank in particular the many sound recordists who placed their recordings for this species on XC and $\mathrm{ML}$. 


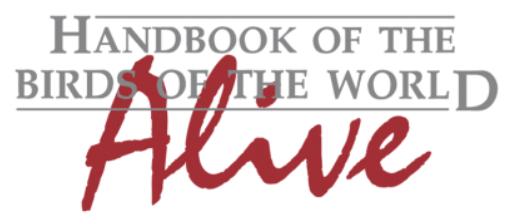

\section{ORNITHOLOGICAL NOTES}
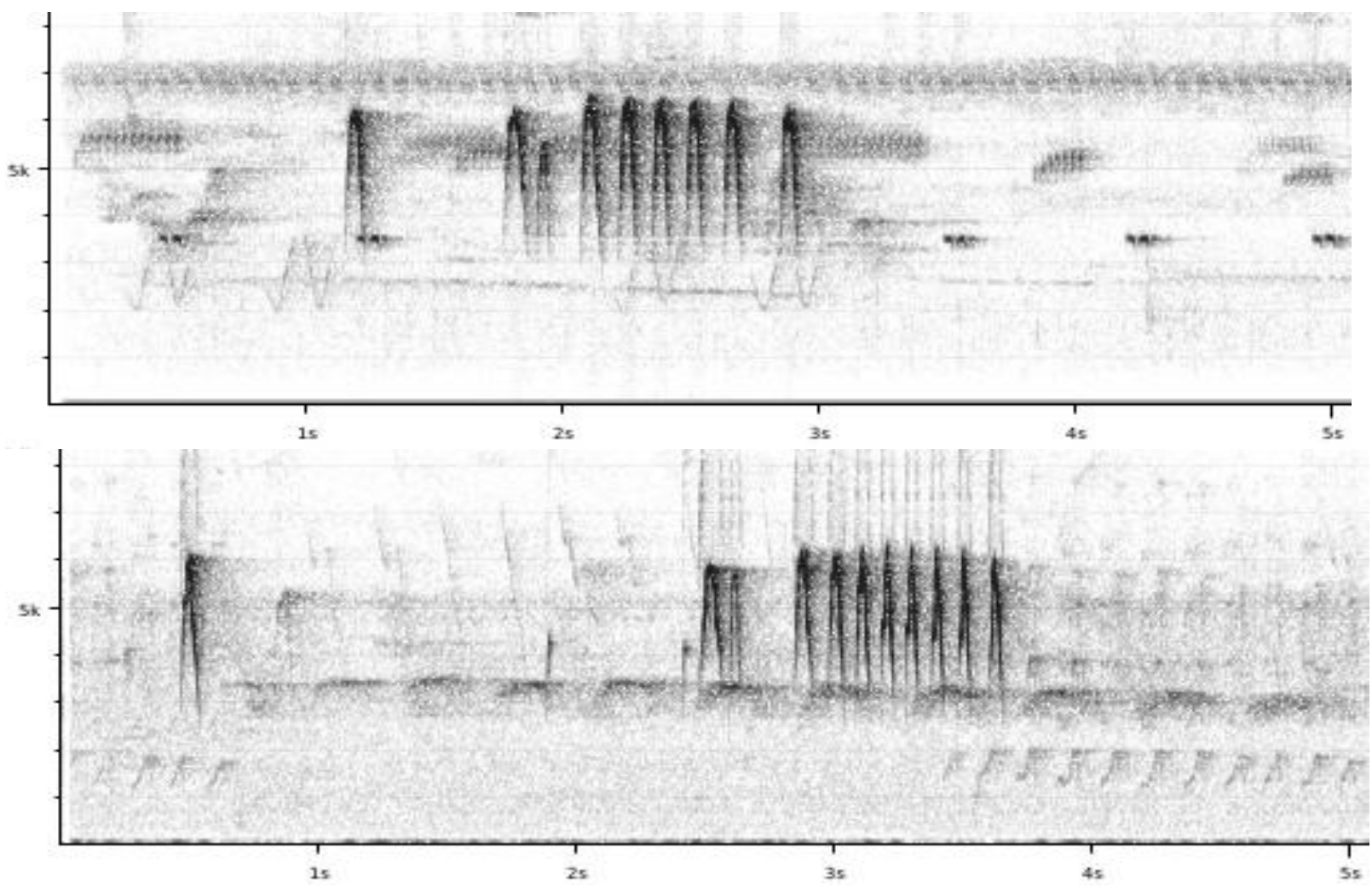

Figure 1: Typical song of western birds (top) and eastern birds (bottom)

\section{References}

Tobias, J.A., Seddon, N., Spottiswoode, C.N., Pilgrim, J.D., Fishpool, L.D.C. \& Collar, N.J. (2010). Quantitative criteria for species delimitation. Ibis 152(4): 724-746.

\section{Recommended citation}

Boesman, P. (2016). Notes on the vocalizations of Ornate Flycatcher (Myiotriccus ornatus). HBW Alive Ornithological Note 251. In: Handbook of the Birds of the World Alive. Lynx Edicions, Barcelona. (retrieved from http://www.hbw.com/node/932252 on 4 October 2016). 